Pak. j. sci. ind. res. Ser. B: biol. sci. 2014 57(2) 66-70

\title{
Genetic Analysis of Yield and Yield Components in Diallel Cross of Maize (Zea mays L.) in $\mathrm{F}_{2}$ Generation
}

\author{
Amanullah*; Shah Jehan Khan ${ }^{\mathrm{b}}$ and Muhammad Mansoor ${ }^{\mathrm{a}}$ \\ ${ }^{a}$ Arid Zone Research Institute, Dera Ismail Khan, KPK, Pakistan \\ ${ }^{b}$ Faculty of Agriculture, Gomal University, Dera Ismail Khan, KPK, Pakistan \\ (received March 19, 2013; revised February 19, 2014; accepted February 25, 2014)
}

\begin{abstract}
Genetic analysis was carried out for six maize cultivars and their $30 \mathrm{~F}_{2}$ crosses under agroclimatic conditions at Agricultural Research Institute of Dera Ismail Khan, Pakistan. The analysis of variance indicated highly significant differences among parents and their $\mathrm{F}_{2}$ progeny for all the parameters. The genetic analysis revealed that the characters viz; kernels/ear, kernels rows/ear, kernels/row, ear length, 1000 grain weight and grain yield have shown additive type gene action. According to regression analysis, the non-significant deviation of the regression line from unit slope indicated the absence of non-allelic interaction, which was presented in all the characters.
\end{abstract}

Keywords: genetic analysis, yield components, maize, $\mathrm{F}_{2}$ generation

\section{Introduction}

Maize (Zea mays L.) belongs to the family Gramineae and is an annual, short duration, long day, cross-pollinated and determinate crop. In cereal crops maize attained third position after wheat and rice in world production. Maize is cultivated throughout temperate and tropical regions of the world.

The main objective of the maize breeding programmes is to breed high yielding and well-adapted hybrids/ cultivars. Breeding for improved varieties is a continuous process and requires primarily a thorough knowledge of the genetic mechanism governing yield and yield components. Diallel cross technique developed by Hayman (1954) and Jinks (1954) provides information on the inheritance mechanism in the early filial generations and helps the breeder to make effective selection.

Wolf et al. (2000) estimated additive genetic variances for $\mathrm{F}_{2}$ generation and concluded that yield and other characters were controlled by additive genetic variance. Mufti et al. (2002) conducted diallel analysis of yield and yield components in maize (Zea mays L.). The data were recorded and the nature of gene action was investigated for kernel rows/ear, kernels/row, 100 grain weight and grain yield/plant. $\mathrm{Vr} / \mathrm{Wr}$ graphs indicated that kernels/row; 100 grain weight and grain yield/plant were controlled by over-dominance type of gene action, while, kernel rows/ear was under the control of additive type of gene action. Parentoni et al. (2001) conducted 28 maize open pollinated varieties (OPVs) crossed in

*Author for correspondence; E-mail: panyala64@yahoo.com a diallel scheme. Morphological data showed a higher degree of genetic divergence among the dent germplasm than among the flint germplasm used in this study. Saleem et al. (2002) studied gene action for various quantitative traits in a complete diallel involving six maize populations. Variance/covariance graphs revealed that kernel rows/ear, kernels/row, 100 grain weight and grain yield/plant were controlled by over dominance type of gene action. Soengas et al. (2003) crossed ten open-pollinated flint maize cultivars in a diallel design without reciprocals. Crosses yielded $30 \%$ more than parental cultivars. Mid-parent heterosis values ranged from 2.5 to $64.7 \%$. The crosses 'Gallego' × 'Basto/Enano Levantino' and Basto/Enano Levantino $\times$ 'Longfellow' showed high heterosis and the best average grain yield.

In the present studies, efforts were made to ascertain the gene action and magnitude of contribution of various quantitative characters in a $6 \times 6$ diallel cross experiment of $\mathrm{F}_{2}$ maize populations to evolve new high yielding genotypes through genetic recombination to face global challenges.

\section{Materials and Methods}

The trial was conducted at Agricultural Research Institute, D.I. Khan Pakistan, during the year 2006. Trial was comprised of 6 varieties of maize viz; Kisan, Azam, Sarhad white, Sarhad yellow, Jalal (CCRI, Pirsabak, Nowhere, KPK varieties) and Sadaf (MMRI, Yousaf wala, Punjab variety). The $F_{2}$ population including reciprocals and parental lines were planted in a randomised complete block design with four replications. 
Each treatment consisted of four rows of five meter long with a row spacing of $75 \mathrm{~cm}$ and plant spacing $25 \mathrm{~cm}$. Planting was done on ridges using 2-3 seeds per hill with the help of dibbler, which were later thinned to one plant per hill at four leaves stage. All other agronomic and cultural practices were kept constant for all the treatments from sowing till harvesting.

At maturity 10 plants were randomly selected in each treatment. The data were recorded on kernels/ear, kernels rows/ear, kernels/row, ear length $(\mathrm{cm}), 1000$ grain weight $(\mathrm{g})$ and grain yield $(\mathrm{kg} / \mathrm{ha}$ ) which was subjected to the statistical analysis of variance technique to establish the level of variability among $\mathrm{F}_{2}$ population and their parental lines (Steel and Torrie, 1980).

\section{Results and Discussion}

The results for the analysis of variance are presented in Table 1 and $\mathrm{Wr} / \mathrm{Vr}$ graphic illustration for each trait is presented in Fig. 1-4. The analysis of variance for all the characters revealed highly significant variation, among genotypes including parents and $\mathrm{F}_{2}$ hybrids. All above characters are discussed as follows.

Kernels/ear. A reference to $\mathrm{Wr} / \mathrm{Vr}$ graph plotted in Fig. 1 for $F_{2}$ kernels/ear, indicated that the regression line intercepted the $\mathrm{Wr}$ axis above the origin and denoted additive type of gene action with partial dominance controlling the inheritance pattern of this trait. From the position of array points on regression line it was found that Sarhad yellow, Jalal and Kisan possessed maximum dominant genes by virtue of their nearest position to origin. Cultivars Azam, Sarhad white and Sadaf being away from the origin had the recessive genes.

These findings are in accordance the findings of other workers like Derera et al. (2008); Jumbo and Carena

Table 1. Mean squares and $F$ ratios at 35 \& 105 D.F for analysis of variance for different yields and other traits of maize (Zea mays L.) in $\mathrm{F}_{2}$ generation during 2006

\begin{tabular}{llll}
\hline \hline Parameters & Genotypes & F ratio & C.V\% \\
\hline Kernels/ear & 521.900 & $1.63 \mathrm{NS}$ & 4.667 \\
Kernel rows/ear & 4.250 & $3.47^{* *}$ & 7.741 \\
Kernels/row & 7.936 & $1.32 \mathrm{NS}$ & 8.500 \\
Ear length & 3.464 & $5.15^{* *}$ & 5.914 \\
1000 grain weight & 419.300 & 1.82 & 5.676 \\
Grain yield (kg/ha) & 659346 & 4.27 & 7.930 \\
\hline \hline
\end{tabular}

** = significant at $\mathrm{P} \leq 0.01$.

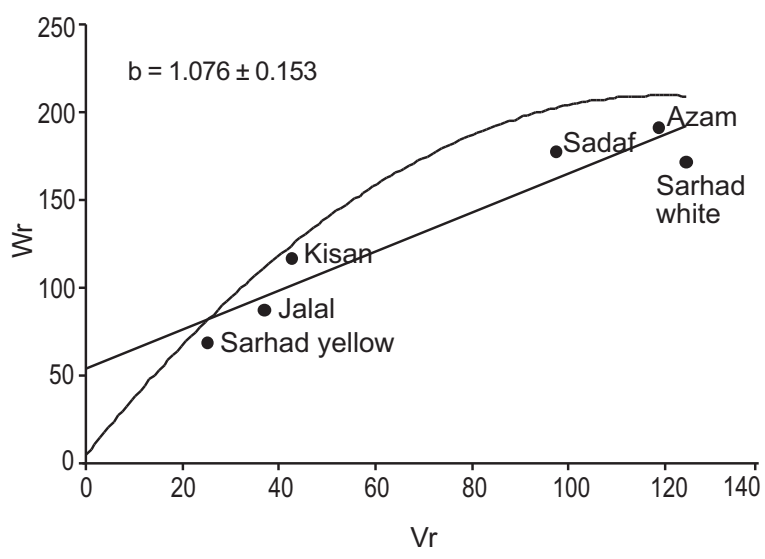

Fig. 1. Wr/Vr graph for kernels/ear.

(2008); Frascaroli et al. (2007), who reported additive type of gene action in manifestation of kernel/ear. However, Kumar et al. (2008) observed non additive type of gene action, which may be due to different genetic background of the cultivars used in different environmental condition.

Kernel rows/ear. The $\mathrm{Wr} / \mathrm{Vr}$ graph plotted in Fig. 2 for $F_{2}$ kernel row/ear, indicated additive type of gene action with partial dominance controlling the inheritance pattern of this trait as the regression line intercepted the $\mathrm{Wr}$ axis above the origin. From the position of array points on regression line it was observed that Sadaf, Jalal, Kisan and Sarhad white seemed to have maximum dominant genes and being nearer to the origin, while the cultivars Sarhad yellow and Azam, being away from the origin due to the recessive genes for kernel rows/ear.

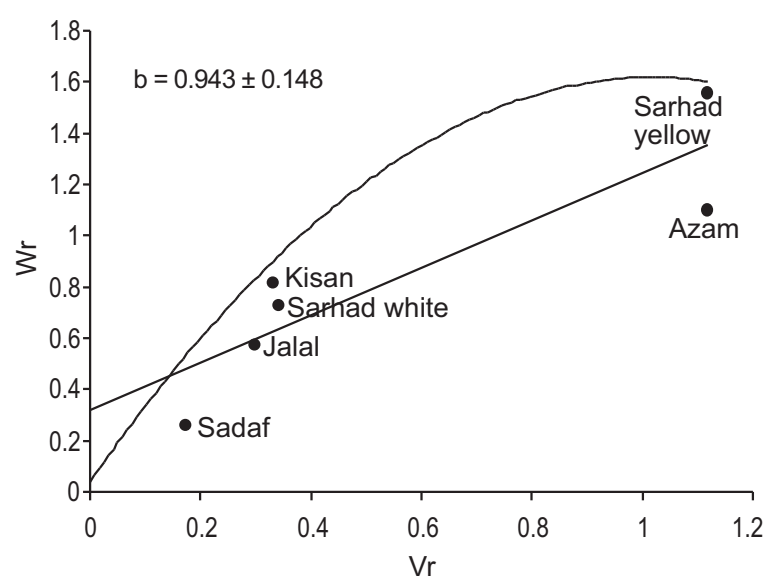

Fig. 2. $\mathrm{Wr} / \mathrm{Vr}$ graph for kernels raw/ear. 
The findings of kernel rows/ear are similar to the results reported by earlier workers like Alam et al. (2008) and Aydin et al. (2007), who reported additive type of gene action in manifestation of kernel rows/ear. However, Kumar et al. (2008) observed non-additive type of gene action, which may be due to different genetic backgrounds of the cultivars used in different environmental conditions.

Kernels/row. The $\mathrm{Wr} / \mathrm{Vr}$ graph plotted in Fig. 3 for $\mathrm{F}_{2}$ kernels/row, indicated additive type of gene action with partial dominance controlling the inheritance pattern of this trait as the regression line intercepted the $\mathrm{Wr}$ axis above the origin. From the position of array points on regression line it was observed that Sadaf and Sarhad white seemed to have maximum dominant genes being nearer to the origin, while the cultivars Sarhad yellow, Azam, Kisan and Jalal being away from the origin had the recessive genes. The kernels/row, showing additive gene affects in $F_{2}$ generation is encouraging because the over dominance causing extra ordinary increase in kernels/row is also not desirable.

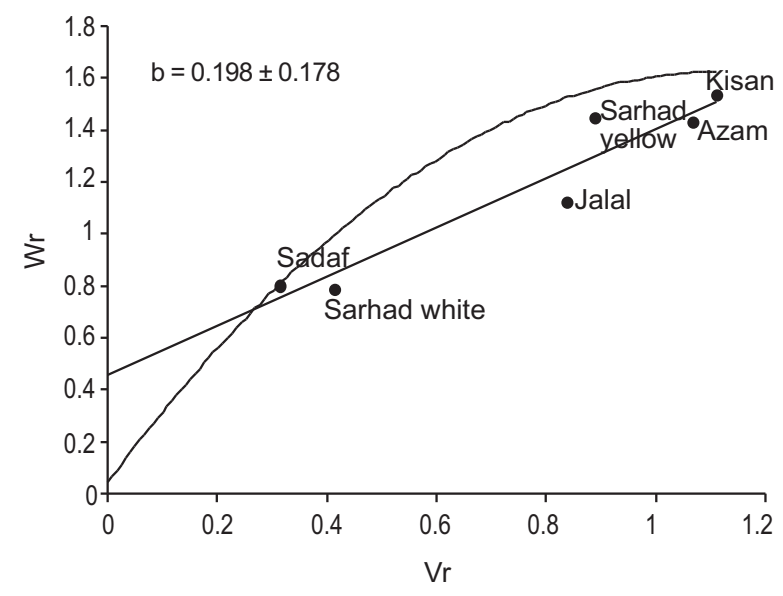

Fig. 3. $\mathrm{Wr} / \mathrm{Vr}$ graph for kernels/row.

Kernels/row is a quantitative character and these findings are in concordance with the conclusion of workers like Zdunic et al. (2008) and Aydin et al. (2007), who reported additive type of gene action in manifestation of kernels/row. However, Kumar et al. (2008) and Tabassum et al. (2007) observed non additive type of gene action, which may be due to different genetic backgrounds of the cultivars used in different environmental conditions.
Ear length. The $\mathrm{Wr} / \mathrm{Vr}$ graph plotted in Fig. $4, \mathrm{~F}_{2}$ ear length, indicated additive type of gene action as the regression line intercepted the $\mathrm{Wr}$ axis above the origin. The position of parental cultivars on the regression line showed that Azam had the maximum dominant genes due to their proximity to the origin, the distal position of Sarhad white and Sarhad yellow indicated maximum recessive genes. The ear length, showing additive gene affects in $\mathrm{F}_{2}$ generation, revealed stability of additive variance.

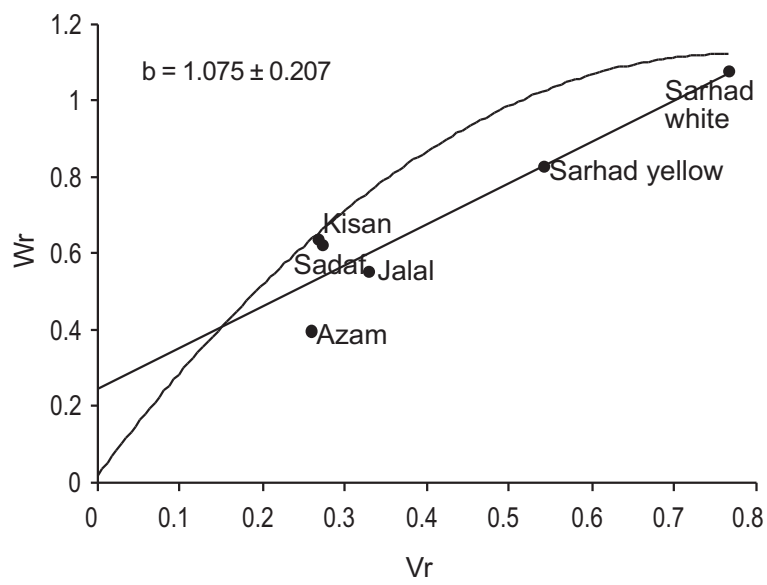

Fig. 4. $\mathrm{Wr} / \mathrm{Vr}$ graph for ear length.

These findings are similar to the results reported by Alam et al. (2008) and Aydin et al. (2007), who reported additive type of gene action in manifestation of ear length. However, Tabassum et al. (2007) observed non-additive type of gene action, which may be due to different genetic backgrounds of the cultivars used in different environmental conditions.

1000 grain weight. It is evident from $\mathrm{Wr} / \mathrm{Vr}$ graph plotted in Fig. 5 that additive type of gene action with partial dominance controlled the inheritance of 1000 grain weight in $\mathrm{F}_{2}$ as the regression line intercepted the $\mathrm{Wr}$ axis above the origin. From the position of array points on regression line it was obvious that only Kisan possessed maximum dominant genes due to maximum and their close position to the origin. The cultivars Sarhad yellow and Azam being away from the origin depicted recessive genes.

These findings are in concordance with the conclusion of workers like Welcker (2005), Aydin et al. (2007) and Alam et al. (2008), who reported additive type of gene action in manifestation of 1000 grain weight. However, 


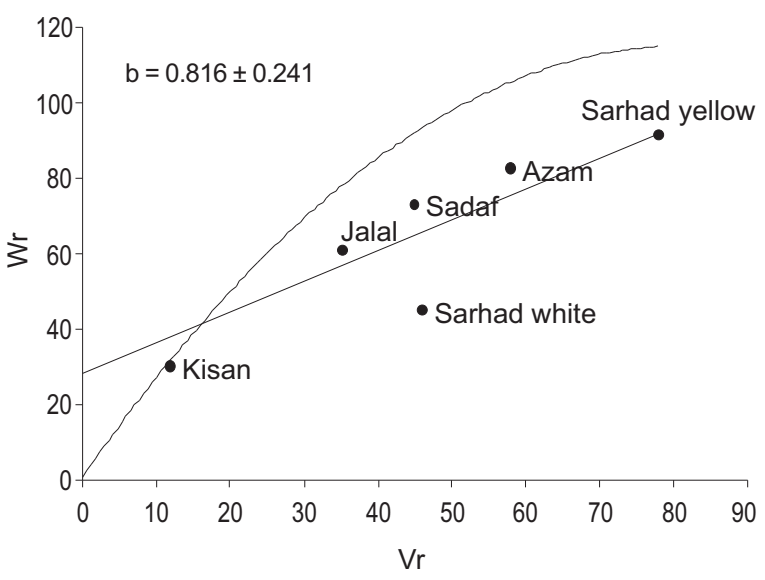

Fig. 5. $\mathrm{Wr} / \mathrm{Vr}$ graph for 1000 grain weight.

Devi et al. (2007) and Tabassum et al. (2007) observed non-additive type of gene action, which may be due to deviation from environmental conditions and genetic material used.

Grain yield $\mathbf{k g} / \mathbf{h a}$. The relationship of $\mathrm{Wr} / \mathrm{Vr}$ graph plotted in Fig. 6 for $\mathrm{F}_{2}$ grain yield $(\mathrm{kg} / \mathrm{ha})$, indicated additive type of gene action with partial dominance controlling the inheritance pattern of this trait as the regression line intercepted the $\mathrm{Wr}$ axis above the origin. The position of array points on regression line showed that Sarhad white, Azam and Sarhad yellow possessed maximum dominant genes and their close proximity to the origin. The cultivars Sadaf and Kisan, being away from the origin had recessive genes.

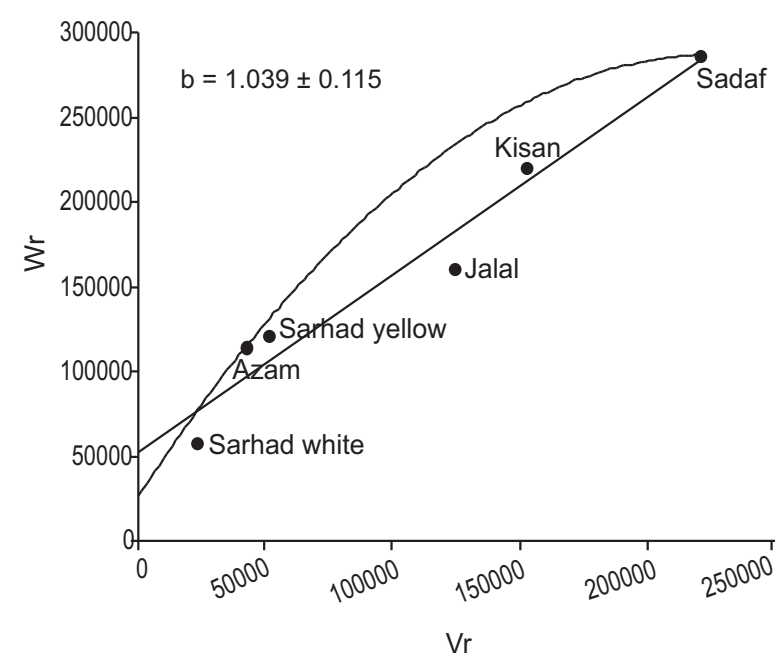

Fig. 6. $\mathrm{Wr} / \mathrm{Vr}$ graph for 1000 grain yield (kg/ha).
Grain yield $(\mathrm{kg} / \mathrm{ha})$ is a quantitative character and these findings are in concordance with the conclusion of workers like Velásquez et al. (2008), Miranda et al. (2008) and Zdunic et al. (2008), who reported additive type of gene action in manifestation of grain yield (kg/ha). However, Ojo et al. (2007) and Tabassum et al. (2007) observed non additive type of gene action, which may be due to different genetic background of the cultivars used in different environmental conditions.

\section{Conclusion}

All the parameters were under the control of additive type of gene action in $\mathrm{F}_{2}$ generation which proved that the selection in early generations would be more effective than late generation for all the characters under study.

\section{References}

Alam, A.K.M.M., Ahmed, S., Begum, M., Sultan, M.K. 2008. Heterosis and combining ability for yield and its contributing characters in maize. Bangladesh Journal of Agricultural Research, 33: 375-379.

Aydin, N., Gokmen, S., Yildirim, A., Ahmlt, O.Z., Figliuolo, A. G., Budak, H. 2007. Estimating genetic variation among Dent Corn inbred lines and top crosses using multivariate analysis. Journal of Applied Biological Sciences, 1: 63-70.

Derera, J., Tongoona, P., Vivek, B., Laing, M.D. 2008. Gene action controlling grain yield and secondary traits in southern African maize hybrids under drought and non-drought environments. Euphytica, 162: 411-422.

Devi, B., Barua, N.S., Barua, P.K., Talukar, P. 2007. Analysis of mid parent heterosis in a variety diallel in rainfed maize. The Indian Journal of Genetics and Plant Breeding, 67: 200-202.

Frascaroli, E., Cane, M.A., Landi, P., Pea, G., Gianfranceschi, L., Villa, M., Morgante, M., Pe, M.E. 2007. Classical genetic and quantitative trait loci analyses of heterosis in a maize hybrid between two elite inbred lines. Genetics, 176: 625-644.

Hayman, B.I. 1954. The theory and analysis of diallel crosses. Genetics, 39: 789-809.

Jinks, J.L. 1954. The analysis of continuous variation in diallel crosses of Nicotiana rustica varieties. Genetics, 39: 767-788.

Jumbo, M.B., Carena, M.J. 2008. Combining ability, maternal and reciprocal effects of elite early- 
maturing maize population hybrids. Euphytica, 162: 325-333.

Kumar, P., Godawat, S.L., Vyas, M., Pandiya, N.K. 2008. Performance of maize (Zea mays) genotypes in different ecological systems. The Indian Journal of Agricultural Science, 78: <http://epubs.icar.org. in/ejournal/index.php/IJAqS/article/view/10337>

Miranda, G.V., deSouza, L.V., Galvão, J.C.C., Guimarães, L.J.M., deMelo, A.V., dosSantos, I.C. 2008. Genetic variability and heterotic groups of Brazilian popcorn populations. Euphytica, 162: 431-440.

Mufti, M.U., Saleem, M., Hussain, A. 2002. Diallel analysis of yield and yield components in maize (Zea mays L.). Pakistan Journal Agricultural Research, 17: 22-26.

Ojo, G.O.S., Adedzwa, D.K., Bello, L.L. 2007. Combining ability estimates and heterosis for grain yield and yield components in maize (Zea mays L.). Journal of Sustainable Development in Agriculture and Environment, 3: 49-57.

Parentoni, S.N., Magalhaes, J.V., Pacheco, C.A.P., Santos, M.X., Abadie, T., Gama, E.E.G., Guimares, P.E.O., Meirelles, W.F., Lopes, M.A., Vasconcelos, M.J.V., Paiva, E. 2001. Heterotic groups based on yield-specific combining ability data and phylogenetic relationship determined by RAPD markers for 28 tropical maize open pollinated varieties. Euphytica, 121: 197-208.

Saleem, M., Shahzad, K., Javid, M., Ahmed, A. 2002. Genetic analysis for various quantitative traits in maize (Zea mays L.) Inbred Lines. International Journal Agriculture \& Biology, 4: 379-382.

Soengas, P., Ordas, B., Malvar, R.A., Revilla, P., Ordas, A. 2003.Heterotic patterns among flint maize populations. Crop Science, 43: 844-849.

Steel, R.D.G., Torrie, J.H. 1980. Principles and Procedures of Statistics: A Biometrical Approach, pp. 172-177, $2^{\text {nd }}$ edition, McGraw Hill, New York, USA.

Tabassum, M.I., Saleem, M., Akbar, M., Ashraf, M.Y., Mahmood, N. 2007. Combining ability studies in maize under normal and water stress conditions. Journal of Agricultural Research, 45: 261-268.

Velásquez, J.C.P., de Souza, C.L., Narro, L.A., Pandey, S., DeLeon, C. 2008. Genetic effects for maize traits in acid and non-acid soils. Genetics and Molecular Biology, 31: 89-97.

Welcker, C., Thé, C., Andréau, B., DeLeon, C., Parentoni, S.N., Bernal, J., Félicité, J., Zonkeng, C., Salazar, F., Narro, N., Charcosset, A., Horst, W.J. 2005. Heterosis and combining ability for maize adaptation to tropical acid soils. Crop Science, 45: 24052413.

Wolf, D.P., Peternelli, L.A., Hallaur, A.R. 2000. Estimates of genetic variance in an $\mathrm{F}_{2}$ maize population. The Journal of Heredity, 91: 384-391.

Zdunic, Z., Mijic, A., Dugalic, K., Simic, D., Brkic, J., Jeromela, A.M. 2008. Genetic analysis of grain yield and starch content in nine maize populations. Turkish Journal of Agriculture and Forestry, 32: 495-500. 